Prepared for the U.S. Department of Energy

under Contract DE-AC05-76RL01830

\title{
The Rise and Decline of U.S. Private Sector Investments in Energy R\&D since the Arab Oil Embargo of 1973
}

JJ Dooley

November 2010

Pacific Northwest

NATIONAL LABORATORY

Proudly Operated by Battelle Since 1965 


\title{
DISCLAIMER
}

This report was prepared as an account of work sponsored by an agency of the United States Government. Neither the United States Government nor any agency thereof, nor Battelle Memorial Institute, nor any of their employees, makes any warranty, express or implied, or assumes any legal liability or responsibility for the accuracy, completeness, or usefulness of any information, apparatus, product, or process disclosed, or represents that its use would not infringe privately owned rights. Reference herein to any specific commercial product, process, or service by trade name, trademark, manufacturer, or otherwise does not necessarily constitute or imply its endorsement, recommendation, or favoring by the United States Government or any agency thereof, or Battelle Memorial Institute. The views and opinions of authors expressed herein do not necessarily state or reflect those of the United States Government or any agency thereof.

\author{
PACIFIC NORTHWEST NATIONAL LABORATORY \\ operated by \\ BATTELLE \\ for the \\ UNITED STATES DEPARTMENT OF ENERGY \\ under Contract DE-AC05-76RL01830
}

Printed in the United States of America

Available to DOE and DOE contractors from the

Office of Scientific and Technical Information,

P.O. Box 62, Oak Ridge, TN 37831-0062;

ph: (865) 576-8401

fax: $(865) 576-5728$

email: reports@adonis.osti.gov

\footnotetext{
Available to the public from the National Technical Information Service, U.S. Department of Commerce, 5285 Port Royal Rd., Springfield, VA 22161 ph: (800) 553-6847 fax: $(703) 605-6900$

email: orders@ntis.fedworld.gov

online ordering: http://www.ntis.gov/ordering.htm
}

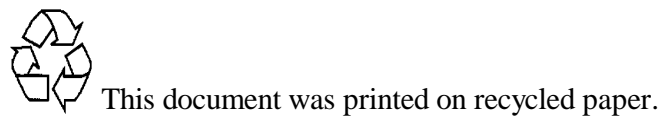




\section{The Rise and Decline of U.S. Private Sector Investments in Energy R\&D since the Arab Oil Embargo of 1973}

JJ Dooley

November 2010

Prepared for the U.S. Department of Energy under Contract DE-AC05-76RL01830 



\begin{abstract}
This paper presents two datasets that describe investments in energy research and development (R\&D) by the U.S. private sector since the mid1970s, which is when the U.S. government began to collect these data systematically. The first dataset is based on a broad survey of more than 20,000 firms' industrial R\&D activities. This broad survey of U.S. industry is coordinated by the U.S. National Science Foundation. The second dataset, conducted by the U.S. Department of Energy's Energy Information Agency, is a narrower accounting of the energy R\&D activities of approximately two dozen of the largest U.S. oil and gas companies. Even given the large disparity in the scope of these surveys, each tells the same story in terms of the broad outlines of the private sector's investments in energy R\&D since the mid 1970s: (1) In the immediate aftermath of the Arab Oil Embargo of 1973, there was a large surge in U.S. private sector investments in energy R\&D that peaked in the period between 1980 and 1982 at approximately \$3.7 billion to \$6.7 billion per year (in inflation adjusted 2010 U.S. dollars) depending upon which survey is used (2) Private sector investments in energy R\&D declined from this peak until bottoming out at approximately $\$ 1.8$ billion to $\$ 1$ billion per year in 1999; (3) U.S. private sector support for energy R\&D has recovered somewhat over the past decade and now stands at \$2.2 billion to \$3.4 billion. Both data sets indicate that the U.S. private sector's support for energy R\&D has been and remains dominated by fossil energy $R \& D$ and, in particular $R \& D$, related to the needs of the oil and gas industry.
\end{abstract}

Key words: Energy R\&D, United States; private sector; deregulation; nuclear energy; fossil energy; oil and gas industry; renewable energy 


\section{Table of Contents}

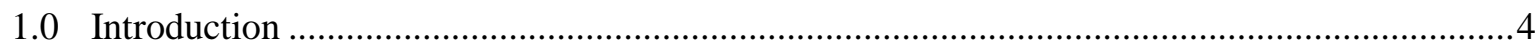

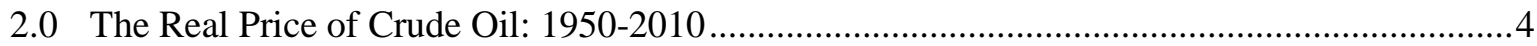

3.0 Trends in U.S. Private Sector Support for Energy R\&D ..................................................

3.1 Findings from the National Science Foundation (NSF) Broad-based U.S. Industrial

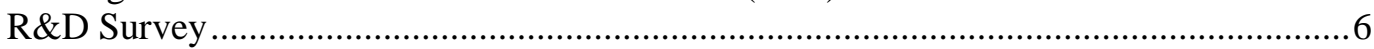

3.2 Findings from the U.S. Department of Energy/Energy Information Agency’s Survey of "Major Energy Producers" ...................................................................................................

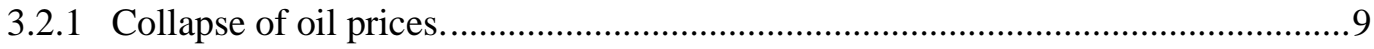

3.2.2 Rapid deregulation of the energy sector, the privatization of formerly state owned oil companies around the world, and the general globalization of the oil

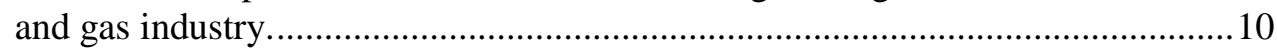

3.2.3 Large scale cost cutting and consolidation in the oil and gas industry..................10

3.2.4 The large scale commercial adoption of new production technologies..................10

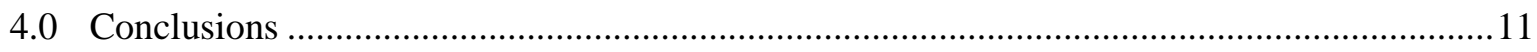

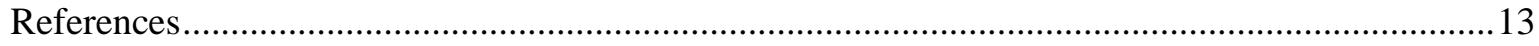

\section{List of Figures}

Figure 1 Real Price of U.S. Crude Oil (2010 U.S.\$ per BBL) and Selected Major Disruptions to World Oil Markets (MBBL/D)

Figure 2: U.S. private sector support for energy R\&D 1973-2005 based on NSF, EPRI and GRI

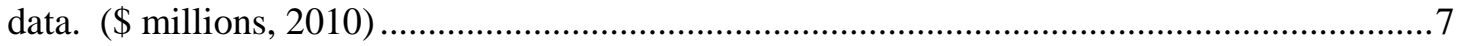

Figure 3: U.S. private sector support by the Major Energy Producers for energy R\&D 1977-2008

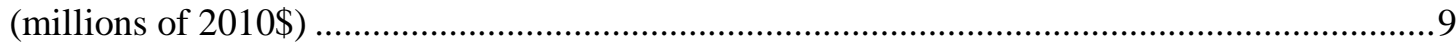

Figure 4: Aggregate U.S. private sector support for all forms of energy R\&D (millions of 2010\$) compared to the real price of crude oil (2010\$/BBL) ............................................................... 12 


\subsection{Introduction}

This paper presents two independent datasets that describe investments in energy research and development $(R \& D)$ by the U.S. private sector since the Arab Oil Embargo of 1973, which is when the U.S. government began to systematically collect these data. The first dataset is based upon the results of a broad survey (more than 20,000 firms) of industrial R\&D administered by the U.S. National Science Foundation (NSF). The second dataset comprises a narrower accounting of energy R\&D activities by the U.S. Department of Energy's Energy Information Agency (EIA) that surveys the R\&D activities of the approximately 20 largest U.S. oil and gas companies.

As the body of this report shows, both datasets tell the same basic story in terms of the broad outlines of the private sector's investments in energy R\&D. Over the period 1977-2005 during which the ranges of the datasets overlap, they reveal a correlation of 0.9, suggesting that each series was recording the same underlying longitudinal trends in private sector investment in energy R\&D .

The purpose of this paper is to explain the observed patterns in U.S. private sector support for energy R\&D investment, which is an important input measure that can shed light on observed rates of technological change in the energy industry. It is not the intent of this paper to analyze the outputs of these private sector investments in energy R\&D, nor to look in great detail at the evolution of individual fields of private energy R\&D over time.

All data in this paper are reported in constant (i.e., inflation adjusted) 2010 U.S. dollars unless otherwise noted. ${ }^{1}$

\subsection{The Real Price of Crude Oil: 1950-2010}

Changes in the real price of energy, particular in the real price of crude oil, are a major driver of aggregate private sector spending on energy $R \& D$ and a strong determinant of the composition of the private energy R\&D portfolio. Therefore, an examination of the history of crude oil prices in the U.S. is an important starting point for an analysis of private sector R\&D investments.

Figure 1 shows the real price of crude oil over the 60 year period from 1950-2010. As this figure shows, there has been significant volatility in the real price of crude oil over this period with the largest price changes occurring between 1973-1980 (650\% increase in the real price of oil); 1980-1989 (450\% decrease in real terms); early 2007 to mid 2008 (real increase of 240\%); and mid 2008 to early 2009 (350\% real decrease in the price of oil).

Over the period, the real price of crude oil has fluctuated between \$40/BBL and \$15/BBL for 70\% of the time. The real price of crude oil has exceeded $\$ 50 / \mathrm{BBL}$ less than $20 \%$ of the time, has exceeded $\$ 75 / \mathrm{BBL}$ approximately $7 \%$ of the time, and has exceeded $\$ 100 / \mathrm{BBL}$ for roughly $2 \%$ of the time.

\footnotetext{
${ }^{1}$ All financial data in this report are reported in inflation-adjusted, real 2010 U.S. dollars unless otherwise noted. The conversion of current, nominal, as-spent dollars (which is how most of these data are reported in the original source materials) to inflation-adjusted 2010 U.S. dollars was computed by using Implicit Gross Domestic Product Price Deflators taken from (BEA, 2010). For 2010, an assumption was made that there would be virtually no inflation and therefore the published value for 2009 was used for 2010 as well.
} 
These same basic price patterns hold if one narrows the period under examination to only the past 20 years (1990 to the present). Since 1990, the real price of crude oil has fluctuated between \$40/BBL and $\$ 15 / \mathrm{BBL}$ for $65 \%$ of the time, exceeded $\$ 50 / \mathrm{BBL}$ approximately $28 \%$ of the time, and exceeded $\$ 75 / \mathrm{BBL}$ and $\$ 100 / \mathrm{bb}, 11 \%$ and $3 \%$ of the time, respectively.

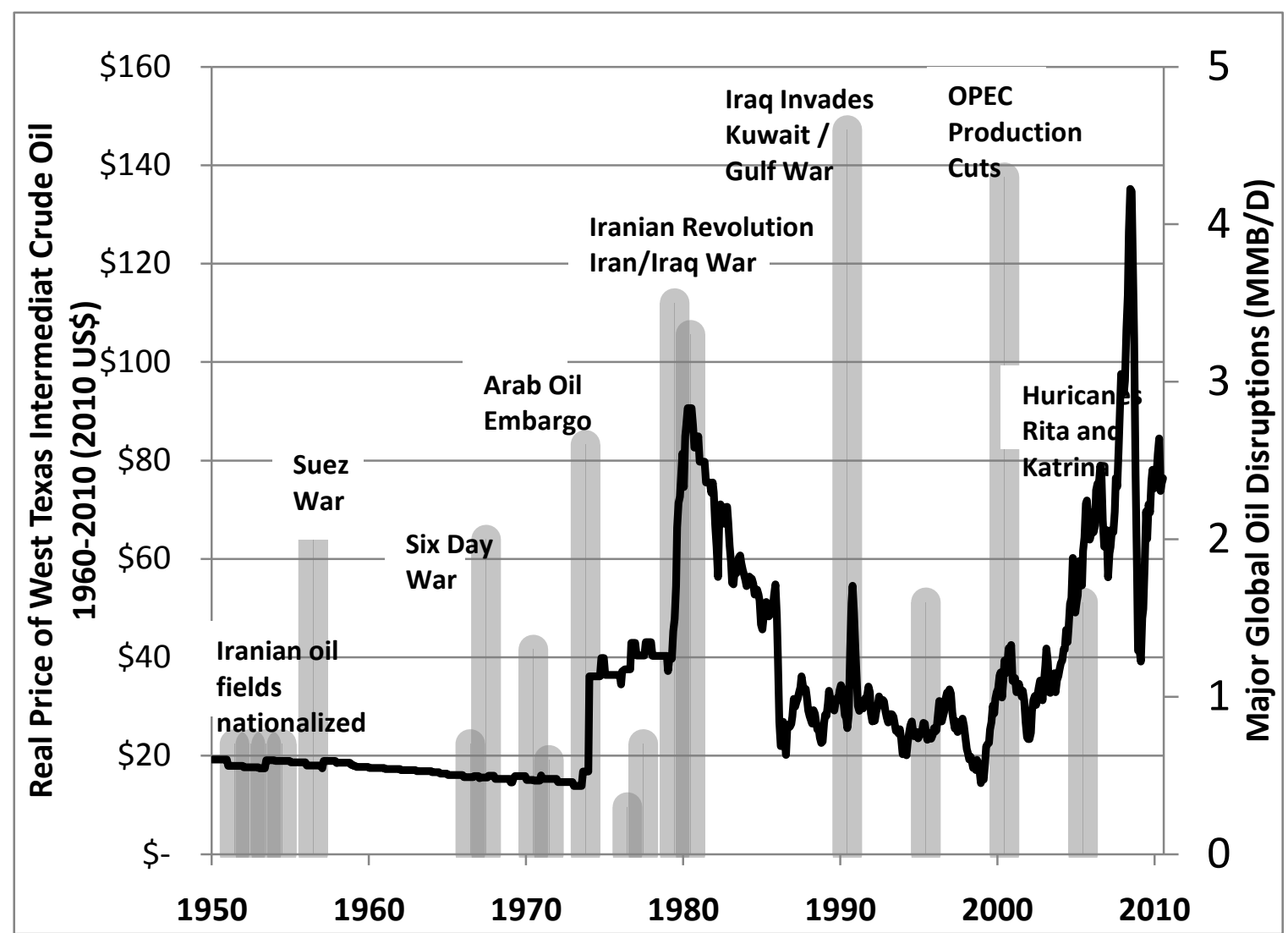

Figure 1 Real Price of U.S. Crude Oil (2010 U.S.\$ per BBL) and Selected Major Disruptions to World Oil Markets (MBBL/D) ${ }^{2}$

\subsection{Trends in U.S. Private Sector Support for Energy R\&D}

The following section describes the independent datasets that describe investments in energy R\&D that lie at the core of this paper's analysis. Both datasets begin in the 1970s in the wake of the Arab Oil Embargo of 1973, which is when the U.S. government began to systematically collect these data.

\footnotetext{
${ }^{2}$ References for Figure 1. Data on the price of West Texas Intermediate Crude Oil from 1950 to the present are from the Federal Reserve (FRED, 2010) while data on global oil disruptions is taken from (EIA, 2005).
} 


\subsection{Findings from the National Science Foundation (NSF) Broad- based U.S. Industrial R\&D Survey}

The NSF Survey is the only official, broad-based U.S. Government survey of industrial R\&D expenditures, with data on more than 20,000 firms. The NSF funds the Department of Commerce's Bureau of the Census to conduct the annual Survey of Industrial Research and Development, collecting data on private-sector support for all forms of R\&D (including energy R\&D) performed by industrial firms with annual R\&D budgets of over \$1 million (Adams and Peck, 1994; NSF, 1976, 1981, 1989, 2000, 2009, 2010b).

The NSF states explicitly that questions pertaining to firms' investments in energy R\&D “were added in the early 1970s, following that decade's oil shortage crisis" (NSF, 2010b). Starting with the 2006 survey year, the NSF and the Bureau of the Census implemented a new survey instrument to assess trends in industry's R\&D efforts and broader innovation activities (NSF, 2010a). Since this revised survey instrument does not contain any questions about industrial support for energy R\&D, the NSF data presented here cover the period 1973-2005.

The NSF/Census data set is unique in its comprehensive coverage of U.S. industry support for energy R\&D. Yet it is also important to note that neither the survey instrument used to collect this data nor the NSF publication that reports the data make reference to any predefined taxonomy of what are considered to be illustrative examples of energy technologies. Furthermore, only the most cursory of definitions is given in the survey instrument as to what is meant by the term "energy R\&D.” Therefore, there is no way of knowing in any detail which energy technologies or technology classes are being developed by industry.

The NSF/Census survey data are combined with two other datasets that describe private sector energy R\&D funding that was carried out by the Electric Power Research Institute (EPRI, 1997, 2001, 2006) and the Gas Research Institute (GRI, 1997, 2001) two large nonprofit energy research organizations in the United States. The addition of the EPRI and GRI datasets is important since they include R\&D funded by or carried out by nonprofit entities that are (e.g., investor-owned electric utilities) not included in the NSF/Census data.

Figure 2 presents the combined NSF, EPRI, and GRI energy R\&D investment data for the period 19732005. Aggregate private sector support for energy R\&D grew during the 1970s in response to the oil crises of 1973-74 and 1979, eventually peaking in 1980 at $\$ 6.7$ billion. The collapse of oil prices in the 1980s and the subsequent deregulation of the oil, gas, electric power industries put significant downward pressure on the private sector's support for energy R\&D throughout the 1980s and 1990s (Dooley, 1998; GAO, 1996). Aggregate private sector investments in energy R\&D bottomed out at approximately $\$ 1.8$ billion in 1999. According to this NSF/Census dataset (including R\&D carried out at EPRI and GRI), private sector support for energy R\&D in the U.S. has recovered somewhat over the past decade and stood at \$3.4 billion in 2005. 


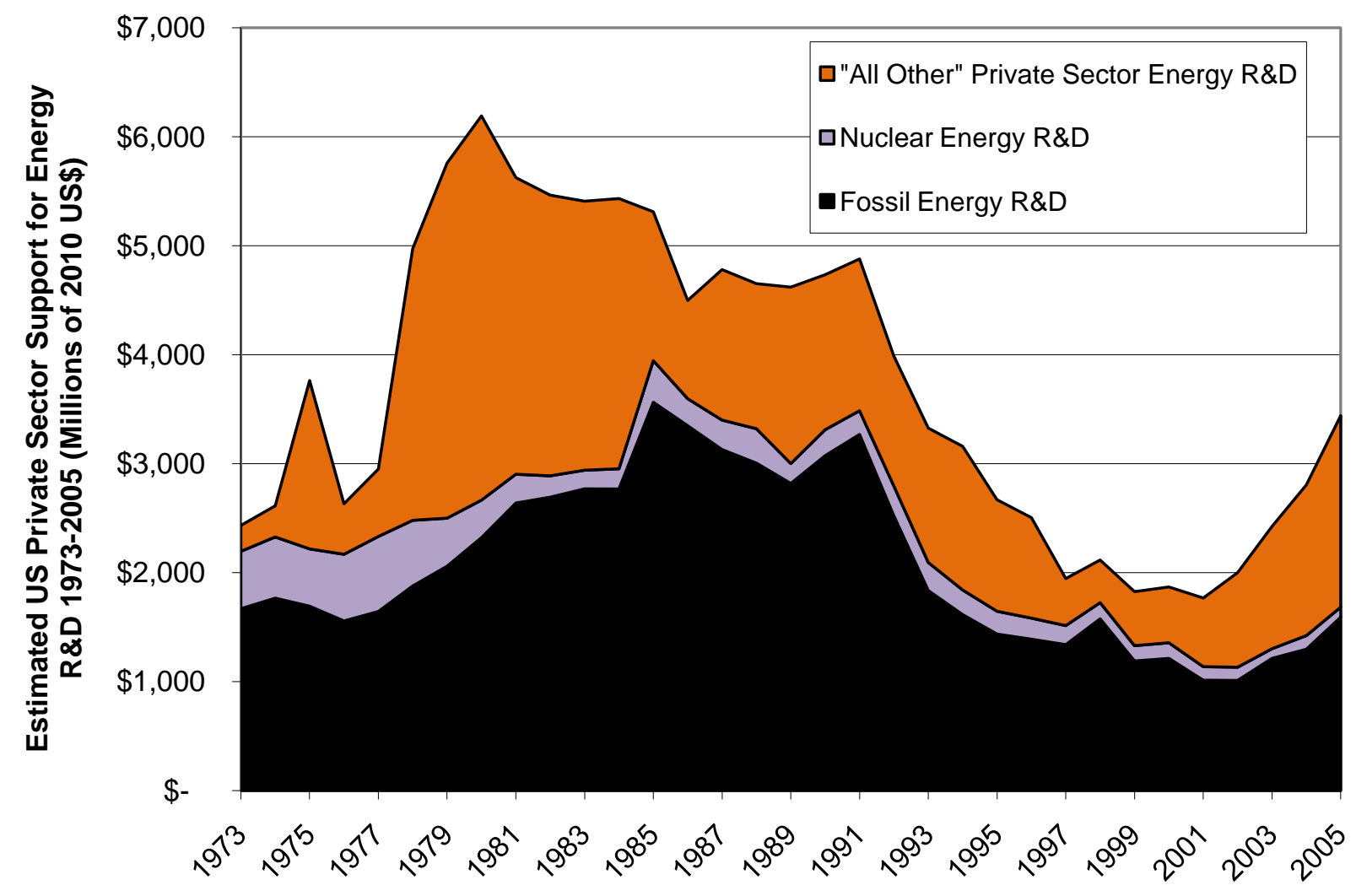

Figure 2: U.S. private sector support for energy R\&D 1973-2005 based on NSF, EPRI and GRI data. (\$ millions, 2010)

Both the NSF/Census and EIA surveys (discussed below) are required to suppress data that could possibly reveal the investment patterns of individual companies, since such information is considered business sensitive. This results in the high level of data aggregation shown in Figure 2 and in the complete suppression of some data in selected years in areas such as renewable energy R\&D or energy efficiency $R \& D$, where investment patterns could easily be attributed to individual firms. Thus, in these years, the significant amount of funding binned under "other energy R\&D” should be viewed as the sum of investments in renewable energy $R \& D$, energy efficiency $R \& D$, as well as energy $R \& D$ investments not classified under a particular fuel type. It is not possible to impute any meaningful trends amongst these constituent parts of the "Other energy R\&D” category over time.

However, it is clear that fossil energy R\&D-particularly core oil and gas production and refining R\&D activities supported by the oil and gas industries-- was a dominant focus of the U.S. private sector's support for energy R\&D over the period 1973-2005, representing more than half of the cumulative private sector investment represented in this dataset. Given the inclusion of R\&D conducted at EPRI in this dataset it is also reasonable to assume that a significant focus of private sector's fossil energy R\&D during the early 1980s and early 1990s was directed at developing technologies for controlling the emissions of criteria air pollutants from stationary point sources mandated by the promulgation of tighter emissions standards (Rubin et al., 2004). For much of the survey period, fossil energy R\&D constituted $60 \%$ to $75 \%$ of the total. 
During the 1970 s, as much as $20 \%$ of private sector investments in energy R\&D was devoted to nuclear (fission) energy R\&D, mainly for the development of new power reactor designs. Once these designs had been developed and deployed at nuclear power plants around the nation, the level and focus of the U.S. private sector's support for nuclear energy R\&D changed. During the 1980s, 1990s and 2000s, nuclear fission energy R\&D typically accounted for only $4 \%$ to $8 \%$ of the private sector's overall energy R\&D effort and these investments became more focused on life-extension technologies for existing nuclear power plants.

\subsection{Findings from the U.S. Department of Energy/Energy Information Agency's Survey of "Major Energy Producers"}

The U.S. Department of Energy's Energy Information Agency annually surveys the energy R\&D efforts of a select group of firms that the EIA classifies as "Major Energy Producers" (EIA, 2009b). Although mergers, acquisitions, and other changes in industry structure affect the composition of the survey sample, the majority of firms surveyed are large oil and gas companies. ${ }^{3}$ The clear focus of these firms on oil and gas production and refining can be seen in the nature of the energy $R \& D$ portfolio they have supported over time. Energy R\&D focused on meeting the needs of the upstream and downstream of oil and gas industries has always been the overwhelming focus of the Major Energy Producers' investments in energy R\&D. However even during the period of the energy crises of the 1970s and early 1980s when there was a clear effort to broaden their energy R\&D portfolio, upstream and downstream oil and gas related R\&D accounted for 65-72\% of all energy R\&D supported by these firms between 1977 and 1984. By 1988, upstream and downstream oil and gas related energy R\&D accounted for $90 \%$ of all of these firms' energy R\&D and it stayed above 90\% until 2003.

Figure 3 reports energy R\&D investments of the Major Energy Producers from 1977 to 2008, the most recent year for which data are available. As with the NSF survey, the EIA survey defines "energy R\&D" only in broad terms and therefore it is not possible to gain insight into the investment levels for specific energy technologies within each of the reported broad energy technology classes (EIA, 2008a).

There are major trends evident in Figure 3, below. First, the Major Energy Producers, like the broader group of industrial R\&D supporters shown in the NSF data, reacted strongly to the oil price shocks of the 1970s with significant increases in energy R\&D investment and by broadening the scope and diversity of their energy R\&D portfolios. The significant investments in coal gasification and liquefaction and in “non-conventional energy R\&D” including renewable energy technologies during this period was a direct response to the oil supply shocks. In 1978-1979, the Major Energy Producers were devoting more than $20 \%$ of all of their energy R\&D to coal-to-liquids and coal gasification research projects.

\footnotetext{
${ }^{3}$ A list of the firms surveyed and how they have changed with time can be found at http://www.eia.doe.gov/emeu/perfpro/CoList.html
} 


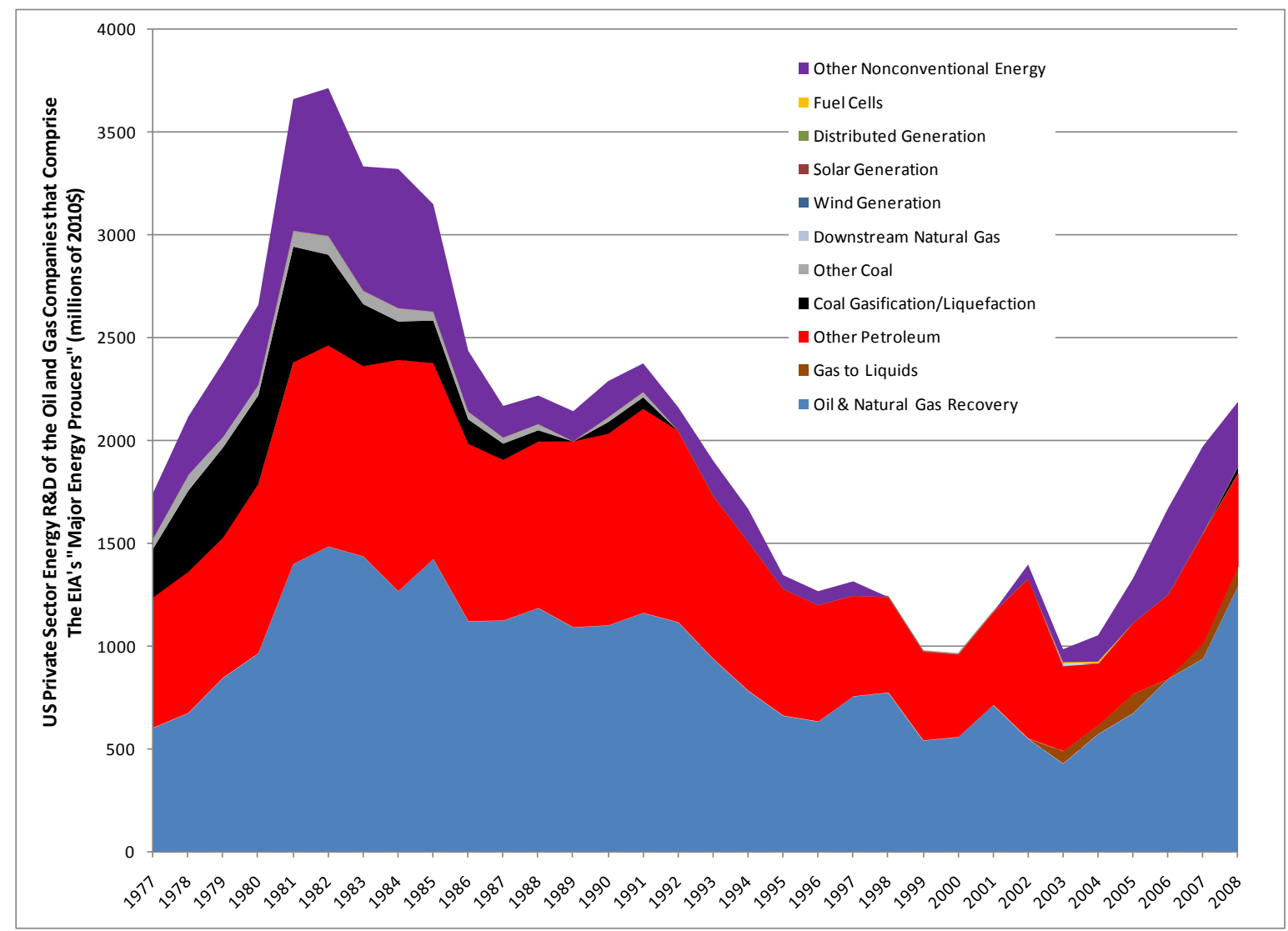

Figure 3: U.S. private sector support by the Major Energy Producers for energy R\&D 1977-2008 (millions of 2010\$)

Because the EIA survey comprises a small number of firms, it is possible to dig deeper into these data to gain a better understanding of the major drivers of the reductions in support for energy R\&D that occurred after 1980. Four key factor help to explain the nearly fourfold decline in the Major Energy Producer’s support for energy R\&D between 1981-2000:

\subsubsection{Collapse of oil prices.}

As early as 1982 and well before the complete collapse of oil prices in 1986, the Major Energy Producers had already started to adjust the level and composition of their support for energy R\&D based on "lowered expectations of future oil prices." In particular, the Major Energy Producers reduced their investments in coal gasification / liquefaction by $17 \%$ in 1982 from the previous year's level (EIA, 1984). In 1986 when global oil prices collapsed, the Major Energy Producers reduced their overall energy R\&D effort by $21 \%$ and reduced their already declining investments in coal gasification / liquefaction by $46 \%$ from 1985 levels (EIA, 1988). 


\subsubsection{Rapid deregulation of the energy sector, the privatization of formerly state owned oil companies around the world, and the general globalization of the oil and gas industry.}

Several key legislative developments in the 1980s and early 1990s set the stage for sweeping deregulation of the U.S. energy industries. These developments included passage of the Petroleum Price and Allocation Decontrol Act of 1981, the repeal of the Power Plant and Industrial Fuel Use Act in 1987, and the passage of the Natural Gas Wellhead Decontrol Act of 1989 and the Energy Policy Act of 1992. The net effect of these legislative actions was the deregulation of the U.S. oil and gas industries allowing oil and gas firms to be more nimble in moving into new areas of growth and shedding underperforming businesses (EIA, 2002b, 2009a). Deregulation in the U.S. coincided with the collapse of the Former Soviet Union and the precipitous decline in crude oil production from this region during the late 1980s and early 1990s, which presented significant new opportunities for the Major Energy Producers to move into new lower cost producing regions that required the application of existing technologies, additional capital and better management techniques to expand production (EIA, 1996; Reynolds and Kolodziej, 2008). In these areas, the Major Energy Producers could deliver value to their shareholders without significant investments in energy R\&D and new energy technologies. This dynamic can be seen in Figure 3 in terms of the significant real reduction in support for oil and gas recovery R\&D during the late 1980s and early 1990s.

\subsubsection{Large scale cost cutting and consolidation in the oil and gas industry.}

Throughout the 1980s and particularly after the oil price collapse of1986, the Major Energy Producers underwent significant restructuring and divestiture of non-core businesses. As a result, major firms became more tightly focused on upstream oil and gas production than they had been when oil prices hit their peak in 1980 (EIA, 1988). By 1990, for example, ARCO had sold off its solar manufacturing subsidiary, Unocal had ended its oil shale operations, and the Major Energy Producers as a group had completely exited the coal gasification / liquefaction business. Oil companies' once significant role in the production of uranium oxide $\left(\mathrm{U}_{3} \mathrm{O}_{8}\right)$ for the nuclear fuel industry also declined sharply and ceased completely by 1991 (EIA, 1984, 1988, 1991, 2002a). The Major Energy Producers' exit from solar energy was all but complete by 1995 when Mobil sold its solar division in 1993 and Amoco spun its solar activities off into a joint venture with Enron (EIA, 1996). With the narrowing of these firms' business focus on core oil and gas industry activities there was less and less rationale for them to support energy $\mathrm{R} \& \mathrm{D}$ in nonconventional energy $\mathrm{R} \& \mathrm{D}$ areas and this trend is quite clear Figure 3 during the 1980s and 1990s. The Major Energy Producers also slashed their workforces during this period, shedding approximately 600,000 between1982 to 1994 including a reduction of 165,000 between 1990-1994 (EIA, 1996).

\subsubsection{The large scale commercial adoption of new production technologies.}

The 1980s and 1990s saw the large scale commercial adoption of a handful of key new technologies by the Major Energy Producers. The successful commercial deployment of these new technologies allowed the Major Energy Producers to lower production costs and open up new areas for energy extraction. Some of the notable technological advancements during this time period included: 
a. The successful development and application of three dimensional seismic exploration facilitating more effective exploration and production in the Gulf of Mexico and other offshore areas (EIA, 1991, 1996);

b. Shell's completion, in 1990, of the first tension leg deep water platform that allowed it and eventually other firms to begin producing in water depths greater than half a mile (EIA, 1991, 1996).

c. By the late 1980s, horizontal drilling techniques had become common place and allowed for far higher rates of recovery from oil fields (EIA, 1991).

d. Increasing use of enhanced oil recovery techniques and the growth of its large infrastructure of $\mathrm{CO}_{2}$ pipelines by the end of the 1980s,paved the way for expanded domestic supplies through tertiary oil production U.S. (Dooley et al., 2009; EIA, 1991).

e. Large scale commercial adoption of advanced longwall coal mining techniques in the early 1990s significantly reducing coal production costs for the subset of Major Energy Producers that had significant coal business lines (EIA, 1996).

f. Recent advances in hydraulic fracturing and horizontal drilling that have opened up large deposits of previously uneconomic to produce natural gas in shale deposits (EIA, 2008b).

The successful large scale adoption of these and other new energy technologies also helps to explain the decline in overall investment levels by the Major Energy Producers during the 1980s and 1990s. Since private sector investments in $\mathrm{R} \& \mathrm{D}$ are largely applied needs-oriented research, the successful deployment of technologies resulting from previous investments in energy R\&D activities reduces the need for further innovation at least in these selected domains. Collectively, these four phenomena resulted in a smaller energy R\&D portfolio with a tighter focus on core activities such as oil and gas recovery and refiningrelated R\&D that was evident during the period that spanned much of the 1990s to the early 2000s.

In recent years, the Major Energy Producers have started to devote up to one-quarter of their overall energy R\&D effort to what is broadly categorized by the EIA as “other nonconventional energy R\&D” implying that up to $75 \%$ of these firms' energy R\&D effort is still unsurprisingly focused on their core business activity of finding, producing and refining petroleum and natural gas. It is not possible to determine with any precision what kinds of energy R\&D is being supported by the Major Energy Producers in this growing other nonconventional energy R\&D” category from the data published by the EIA, but it seems reasonable to assume that some aspect is related to biofuels and carbon capture and storage two areas where these firms are becoming important sponsors of R\&D (EIA, 2007; Plasynski, 2007). Many of the Major Energy Producers are involved in either the production of Canadian tar sands or refining these feedstocks into finished products and therefore it seems reasonable that some of the recent growth in "oil and natural gas production” could be in these areas (EIA, 2008b, 2009b).

\subsection{Conclusions}

Figure 4 shows aggregate private sector support for energy R\&D from each of these surveys along with the real price of crude oil. Even given the large disparity in the breadth and scope of these two 
surveys, both datasets tell the same story in terms of the broad outlines of the private sector's investments in energy R\&D since the mid 1970s. The data show that in the immediate aftermath of the Arab Oil Embargo of 1973, there was a large surge in U.S. private sector investments in energy R\&D that peaked in the period between 1980 and 1982 at approximately \$3.7 billion to \$6.7 billion per year (in inflation adjusted 2010 U.S. dollars) according to the NSF and EIA datasets, respectively. Private sector investments in energy R\&D declined from this peak to a nadir of approximately $\$ 1-\$ 1.8$ billion per year in 1999. U.S. private sector support for energy R\&D has recovered somewhat over the past decade and now stands at \$2.2-\$3.4 billion. Both data sets indicate that the U.S. private sector's support for energy $R \& D$ has been and remains dominated by fossil energy $R \& D$, particularly R\&D related to the needs of the oil and gas industry. Both data sets also show that private sector investments in energy R\&D were strongly correlated to real price of crude oil throughout the 1970s and 1980s. That correlation has weakened substantially since the 1990s, suggesting that R\&D aimed at developing non-fossil energy alternatives may have become a more prominent and durable private sector energy R\&D priority.

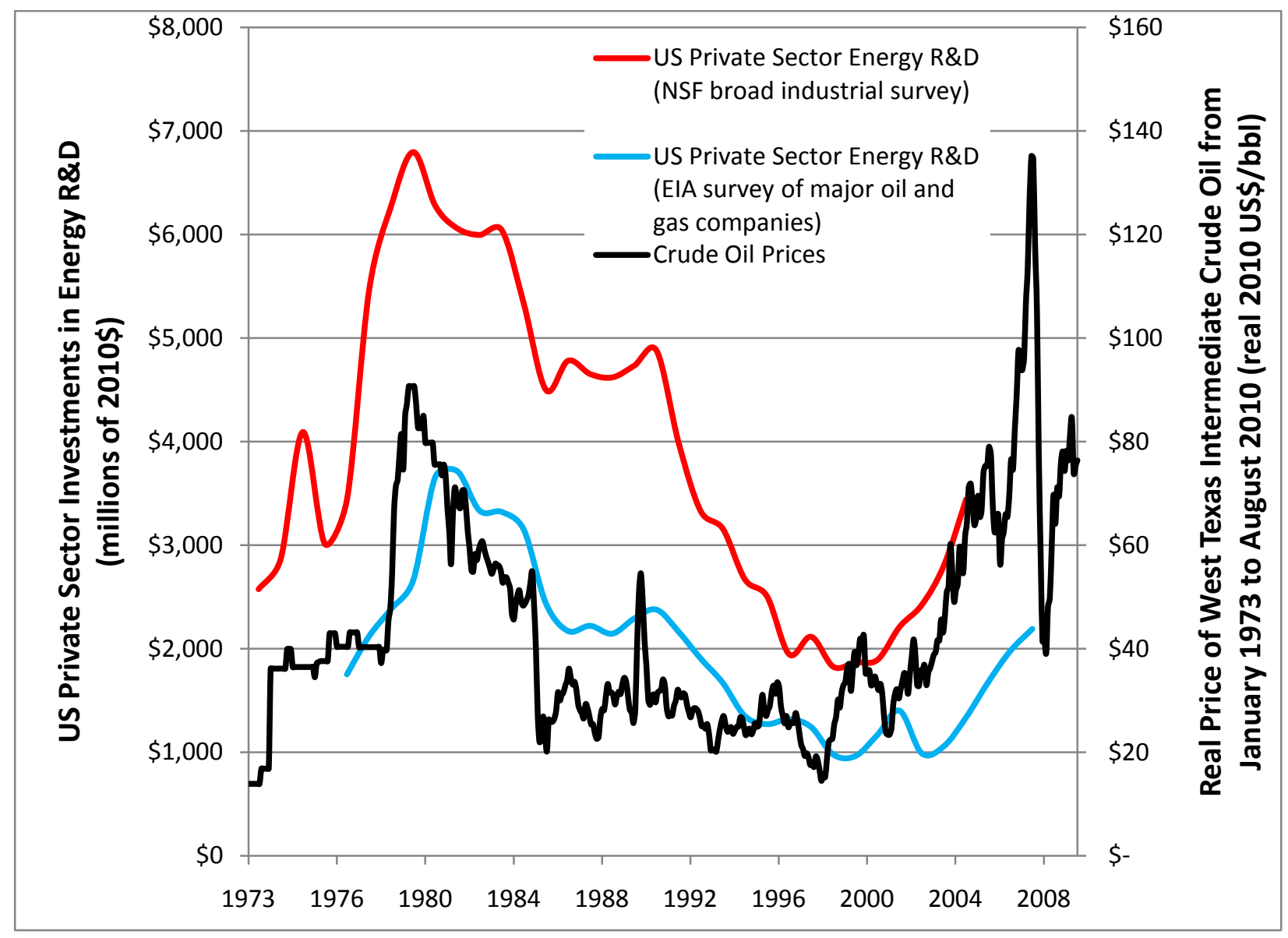

Figure 4: Aggregate U.S. private sector support for all forms of energy R\&D (millions of 2010\$) compared to the real price of crude oil (2010\$/BBL) 


\section{References}

Adams, J, Peck, S, 1994. A Guide to R\&D Data at the Center for Economic Studies, U.S. Bureau of the Census. Center for Economic Studies, U.S. Bureau of the Census, Washington, DC.

BEA, 2010.Table 1.1.9. Implicit Price Deflators for Gross Domestic Product Bureau of Economic Analysis, US Department of Commerce. 9/9/2010.http://www.bea.gov/national/Index.htm.

Dooley, J, 1998. Unintended consequences: energy R\&D in a deregulated energy market. Energy Policy 26, 547-555.

Dooley, J, Dahowski, R, Davidson, C, 2009. Comparing Existing Pipeline Networks with the Potential Scale of Future U.S. $\mathrm{CO}_{2}$ Pipeline Networks. Energy Procedia 1, 1595-1602.

EIA, 1984. Performance Profiles of Major Energy Producers 1982. Energy Information Administration, US Department of Energy, Washington, DC, p. 147.

EIA, 1988. Performance Profiles of Major Energy Producers 1986. Energy Information Administration, US Department of Energy, Washington, DC, p. 168.

EIA, 1991. Performance Profiles of Major Energy Producers 1990. Energy Information Administration, US Department of Energy, Washington, DC, p. 190.

EIA, 1996. Performance Profiles of Major Energy Producers 1994 Energy Information Administration, US Department of Energy, Washington, DC, p. 147.

EIA, 2002a. Performance Profiles of Major Energy Producers 2000. Energy Information Administration, US Department of Energy, Washington, DC, p. 146.

EIA, 2002b. Petroleum Chronology of Events 1970 - 2000. Energy Information Agency, US Department of Energy, Washington, DC.

EIA, 2005.Global Oil Supply Disruptions Since 1951. Energy Information Agency, US Department of Energy. http://www.eia.doe.gov/emeu/security/distable.html.

EIA, 2007. Annual Energy Outlook 2007 with Projections to 2030. Energy Information Administration, US Department of Energy.

EIA, 2008a. EIA-28: Financial Reporting System Instructions (Reporting Year 2008). Energy Information Agency, US Department of Energy, Washington, DC, p. 70.

EIA, 2008b. Performance Profiles of Major Energy Producers 2007. Energy Information Administration, US Department of Energy, Washington, DC, p. 110.

EIA, 2009a. Major Legislative and Regulatory Actions (1935 - 2008). Energy Information Agency, US Department of Energy, Washington, DC.

EIA, 2009b. Performance Profiles of Major Energy Producers 2008 Energy Information Administration, US Department of Energy, Washington, DC, p. 96. 
EPRI, 1997. Special Tabulation of the Electric Power Research Institute's Annual Budgets 1973-1997. Dale Eldredge, Director of Finance, Electric Power Research Institute, Palo Alto, CA.

EPRI, 2001. EPRI budget data for 1998 and 1999 Personal communication from Robert Schock, Palo Alto, CA.

EPRI, 2006. Special Tabulation of the Electric Power Research Institute's Annual Budgets 2000-2006. Thom Henneberger, Electric Power Research Institute, Palo Alto, CA.

FRED, 2010.OILPRICE, Spot Oil Price: West Texas Intermediate. Historical data 1946-2010. Federal Reserve Economic Data, Federal Reserve Bank of St. Louis. 2010-08-02.

GAO, 1996. Federal Research" Changes in Electricity-Related R\&D Funding". U.S. Government Accounting Office, Washington, DC, p. 36.

GRI, 1997. Special Tabulation of Annual Budgets 1978-1996. Christina Thomas, State Regulatory Counsel, Policy and Regulatory Affairs Division, Gas Research Institute, Washington, DC, pp. December 15, 1997.

GRI, 2001. Special Tabulation of Annual Budgets 1997-1999. William R. Statts, Gas Research Institute, Washington, DC, pp. April 25, 2001.

NSF, 1976. Research and Development in Industry: 1974. National Science Foundation, Division of Science Resources Statistics, Arlington, VA.

NSF, 1981. Research and Development in Industry: 1979. National Science Foundation, Division of Science Resources Statistics, Arlington, VA.

NSF, 1989. Research and Development in Industry: 1987. National Science Foundation, Division of Science Resources Statistics, Arlington, VA.

NSF, 2000. Research and Development in Industry: 1998. National Science Foundation, Division of Science Resources Statistics, Arlington, VA.

NSF, 2009. Research and Development in Industry: 2004 Detailed Statistical Tables, Arlington, VA.

NSF, 2010a. NSF Releases New Statistics on Business Innovation. National Science Foundation, Division of Science Resources Statistics, Arlington, VA.

NSF, 2010b. Research and Development in Industry: 2005 Detailed Statistical Tables, Arlington, VA.

Plasynski, S, 2007. Carbon Sequestration R\&D Overview. National Energy Technology Laboratory, US Department of Energy, Washinton, DC.

Reynolds, DB, Kolodziej, M, 2008. Former Soviet Union oil production and GDP decline: Granger causality and the multi-cycle Hubbert curve. Energy Economics 30, 271-289.

Rubin, ES, Yeh, S, Hounshell, DA, Taylor, MR, 2004. Experience curves for power plant emission control technologies. International Journal of Energy Technology and Policy 2, 52-69. 